Media Industries 8.1 (2021)

\title{
Taking Netflix to the Cinema: National Cinema Value Chain Disruptions in the Age of Streaming
}

\author{
Diane Burgess ${ }^{1}$ \\ THE UNIVERSITY OF BRITISH COLUMBIA \\ Dburgess [AT] mail.ubc.ca \\ Kirsten Stevens ${ }^{2}$ \\ THE UNIVERSITY OF MELBOURNE \\ Kirsten.stevens [AT] unimelb.edu.au
}

\begin{abstract}
This article explores how international over-the-top (OTT) services impact the national feature film value chain in Canada and Australia. Through this lens, this exploration interrogates the tendency to equate distribution technology with legacy release models. When services like Netflix engage with film industry logics, their role expands beyond that of a content distribution portal, with implications for legacy policy mechanisms designed to foster national cinema and preserve domestic intellectual property creation. We question how domestic film production might engage transnational OTT services, what incentives such services have to operate within existing national contexts, and what implications this holds for flow-through to established ancillary markets. Through this, we elucidate the emerging and long-term challenges facing the sustainability of established national cinema ecologies in a changing screen environment. This article offers an intervention into the developing discourse around Netflix as television to ask the question, what does it mean to consider Netflix as cinema?
\end{abstract}

Keywords: Feature Film Value Chain, OTT, SVOD, National Cinema, Netflix

\section{Introduction}

In Netflix Nations, Ramon Lobato acknowledges a persistent ontological uncertainty about digital media services. He asserts that "scholars studying Netflix must therefore make certain choices about what kind of service it is and what the appropriate frames of analysis 
should be." ${ }^{3}$ Lobato situates Netflix in the contexts of television studies-noting the technological and industrial shifts that underpin scholarly debates about the future of televisionand platform studies, with its more lateral focus on communicative networks and computational affordances. However, the participation of transnational over-the-top ${ }^{4}$ (OTT) subscription video-on-demand (SVOD) services-like Netflix and Amazon Prime-in the feature film market raises significant questions about the tendency to perceive streamed content delivery as equivalent to broadcast distribution undertakings. The production of "original" content like Roma (2018), Manchester By the Sea (2016), or Okja (2017)-each of which was released theatrically-differs from the process of financing domestic feature films within national production frameworks. Whether acquired in late stages of production (as were Roma and Manchester By the Sea) or in the development phase (Okja), the participation of OTT services in releasing original feature film content signals a different type of disruption for local film industries to that of a broadcaster.

For digitally distributed cultural productions, key issues are overlooked when distribution technology becomes synonymous with release strategies. In their introduction to a special section of Media Industries, Lotz, Lobato, and Thomas raised a series of "provocations" that target conceptual challenges in the study of Global Internet Television. ${ }^{5}$ One particular assumption that they critique involves "either/or narratives" that pit internet-distribution technologies against legacy distribution technologies rather than considering how coexistence and reconfiguration tend to "expand television's ecosystem.." But what would happen if this provocation were directed instead at grasping the expansion of cinema's ecosystem? Specifically, what happens when internet-distribution technologies are pitted against legacy exhibition models?

When Netflix seeks to secure Official Competition slots at Cannes, ${ }^{7}$ or to ensure Oscar eligibility for their films, ${ }^{8}$ there is clear engagement with the logics of the film industry. These actions appear to pose an existential crisis for cinema-can a streamed feature-length production be celebrated as a film?- even though the ensuing controversy suggests it is actually more of a power struggle rooted in the political economy of film exhibition. That said, there is a deeper ontological question raised here about how the logics of the film industry, especially as they pertain to measures of value, can operate separately from legacy release models. Thus, when digital media services participate in the film industry-acting as more than just distribution portals-it is necessary to shift the interdisciplinary lens to consider a film studies perspective on Netflix as cinema.

Our goal in this article is to reposition debates around the impact of Netflix and other OTT SVOD services to engage with a wider screen ecology. Examining examples from Canada and Australia, we seek to draw attention to the ways in which film sustains and develops its industry within a national production context. Specifically, in looking at the way films attain value-both symbolically and economically-and the means by which such value is reinvested into a national industry in the form of financing and networking (such as that which occurs on festival circuits), this article seeks to add a much-needed layer to the discussion of how OTT services generally and Netflix as the most dominant international player are impacting national screen industries. 


\section{What If Netflix Is Cinema?}

With the reconfigurations wrought by digital distribution, we are interested in how the logics of the film industry manifest in the operation of OTT services that exceed their role as content distribution portals. In their disaggregated definition, Lotz, Lobato, and Thomas use "professionalized, industrial practices" (or "industrial logics") as a basis to distinguish between internet-distributed television and internet-distributed film as subcategories of internetdistributed video. ${ }^{9}$ They acknowledge porous terminology and industry overlap occupied by services that distribute content from both subcategories. This inherent hybridity raises the prospect of an alternative pathway (beyond the scope of their television-oriented approach) that considers distribution portals in the context of multiple production processes. Lobato and Lotz refer to the hybridity of Netflix's connections with film and television that "feed confused perceptions of the company," 10 but their subsequent reference to the company's disruption of "established norms of international video distribution"11 sets up an approach to Netflix that is grounded in international broadcasting and pay TV (in conjunction with the Global Internet Television Consortium's research network). To return to the provocation against "either /or narratives," involve a reconfiguration of film industry logics.

There appear to be two issues that impact the perception that Netflix is not cinema. First, as Lobato has noted, "much of the existing coverage of digital distribution has come from outside the discipline of film studies." ${ }^{" 13}$ Where a media studies perspective can be observed in research about Netflix, it tends to take the form of analyses of film culture and the changes in the consumption landscape that characterize on-demand viewing behaviors. ${ }^{14}$ A second issue, separate from the disciplinary orientation of researchers, arises from the apparent agreement that Netflix is more closely aligned (ontologically speaking) with television. With very few exceptions, ${ }^{15}$ Netflix tends to figure less prominently in analyses of cinema in the digital era. It is interesting to note how content type appears to shape the perception of the distribution portal, as evidenced in divergent research agendas for MUBI and Netflix. In particular, any involvement with television seems to invoke ancillary market connotations for films. Researchers who bring a film studies perspective to the study of on-demand digital distribution largely focus on platforms like MUBI that are associated with art cinema and cinephilia. ${ }^{16}$ For example, Fisher, in his analysis of the short-lived African Film Library, points to the emergence of a powerful new intermediary and suggests that "the streaming model is more likely to threaten the availability of niche films, rather than preserve it."17 He notes the potential precariousness of availability (and especially of long-term archival access) that can occur when online distributors attain an unprecedented level of control over content. Although Fisher's analysis remains entrenched in distribution and long-tail exploitation, his concerns begin to approach some of the implications of streaming for national cinemas.

The more cinephilic examinations of digital distribution tend to deal with content accessfrom de-/re-/new-intermediation ${ }^{18}$ to digital rights management, ${ }^{19}$ the dominance of content suppliers, ${ }^{20}$ and the visibility of national cinema. ${ }^{21}$ In "What happened? The Digital Shift in Cinema," Dixon appears to convey anxiety about diminished intermediation-based on "clumsy algorithms"-and wonders how "a film [can] gain traction" without a theatrical 
release. $^{22}$ On the topic of cultural mediation, Frey asserts that video-on-demand (VOD) recommender systems need to be understood in the context of continuities with other media consumption guides (e.g., festival programs, video store clerks) ${ }^{23}$ In seeking a "functional archaeology of cultural recommendation and media consumption choice," ${ }^{24}$ Frey charts a more moderate position relative to the fraught debate over how digital disruption impacts the shaping of taste and cultural preference. References to taste and the disruption of hierarchies of cultural value (on a polarized continuum from utopian de-intermediation to new regimes of marketing surveillance) suggest a digital restaging of the art house versus mainstream distinction that pushes Netflix outside of cinephilic studies of SVOD.

Nostalgia is a prevalent undercurrent that tends to bind cinephilia to cinemas, perhaps in reverence to the rarefied conditions of theatrical viewing but likely more as a nod to the sociality of taste in cultural consumption. When Dixon declares that "film is dead," he appears to be particularly concerned about how the loss of theatrical release (which put films "on the same playing field") marginalizes art cinema in favor of franchise films and a "dumbed down" conversation-while the proliferation of digital content struggles with discoverability. ${ }^{25}$ Frey, in contrast, conveys awareness of the false discontinuity associated with the notion of "internet-based domestic spectatorship," given that home-viewing of films pre-dates the rise of streaming. ${ }^{26}$ Yet, he notes that the "c" of cinema studies "has been melting into a big 'M' of SCMS." ${ }^{27}$ For both researchers, Netflix is firmly associated with post-cinema, either as a synecdoche for mainstream SVOD platforms or as the "key (and will soon be the chief) gatekeeper" 28 in a streaming universe dominated by serial drama as the (pre)dominant cultural format. This article seeks to explore the continuities of an expanded cinema ecosystem-retaining the " $c$ " in the interdisciplinarity of cinema and media studies, minus the nostalgia for linear release windows.

Going a step further, thinking about national cinema in terms of triggers for state support invokes a geographically bounded audience or citizenry (including both consumers and producers of content) and draws attention to regulatory definitions of national content (encompassing both content-producers and content-providers). It is with these different types of disruptions in mind that this article turns to the example of national cinema and the experiences in Canada and Australia.

The focus on Canada and Australia stems from the authors' own backgrounds and the discovery, through multiple conversations, of similarities in how Netflix fits within national screen ecologies and policy debates across the two nations. As comparatively small, Englishlanguage ${ }^{29}$ subsidized cinemas, the cases of Canada and Australia revealed many shared challenges. Yet, in looking more closely, incongruities also emerged. The resulting article thus sits within a legacy of research that engages the "similar-but-different" quality of Canadian and Australian cultural systems. ${ }^{30}$ In the context of film production, this similar-but-different quality works to emphasize the universality of the disruptive effect of Netflix on established national film industries while also highlighting the local specificities that shape how such disruptions play out in each national context. The value of this comparison then, as Annette Van Den Bosch and Alison Beale have noted, is that "The mirrors that Australia and Canada hold up for each other are also magnifying glasses." ${ }^{31}$ While unique in some ways, the experiences of both Canada and Australia work collectively to highlight the need to address the wider impacts that a changing media environment has for national screen industries. 


\section{The Feature Film Value Chain}

Netflix officially arrived in Canada in September 2010 and in Australia in March 2015. ${ }^{32}$ In both instances, the official launch was quickly followed by market dominance. In May 2018, a report by the Australian Communications and Media Authority found that "half of Australian adults (50 per cent) had access to Netflix in the home." ${ }^{33}$ Similarly, by 2018, "close to half of all Canadian households [were subscribed] to the service,"34 placing the number of Canadian Netflix subscribers at just over 6.7 million households. ${ }^{35}$

Faced with the growing popularity of Netflix in both Canada and Australia, discussions of the service have tended to focus on its place as a competitor to and disruptor of terrestrial television formats. However, it is useful to remember Netflix's initial involvement in DVD-bymail subscriptions (and the comparisons to Blockbuster) in order to reconsider how they navigated the technological transformations of the digital era as an online (home) entertainment service. Their involvement on the international film festival circuit and with theatrical distribution points to a diversified perspective on the creation of original VOD content that disrupts traditional content classifications that are based on legacy formats and windowed releasing. In an article in The Guardian, Stuart Heritage noted the somewhat uncomfortable inconsistencies in marketing strategies that arise from Netflix's status as a "catch-all disrupter" that wants to "drag people away from cinemas" and also to "chop the legs out from underneath the likes of Lifetime." 36 If we consider how Netflix impacts state-supported national cinemas, then regulatory concerns expand to encompass policy interventions aimed at fostering the production and consumption of theatrical feature films.

As a conceptual model, the feature film value chain maps the progression of a project from creation to delivery and has been utilized to examine both the commodity (at points of investment and recoupment) and its economic impact (on creative industry sectors). ${ }^{37}$ Despite variations that cluster distribution platforms (to suggest flexible multiplatform releasing) or arguments that independent distributors might encounter a paradigm shift toward a "demand-led" value chain, ${ }^{38}$ it appears that the heuristic ideal of sequential exhibition windows is fully entrenched as a way of understanding content delivery. For example, in their exploration of the potential changes brought by digital distribution, Cunningham and Silver refer to "TV, computers and mobile devices" as "the 'second', 'third' and 'fourth' screens" and note that "cinema was first." ${ }^{39}$ Similarly, the Canadian statutory definition of broadcasting excludes program transmission intended for "performance or display in a public place." ${ }^{40}$ It is possible that the development of these distinctions follows the historical emergence of different screens (and screening contexts) as much as it reflects industrial progression of sequential windows. Either way, in the value chain model, SVOD services are situated among the content delivery platforms, segregated from cinema (as theater screen).

However, it is important to recall Bloore's assessment of the limitations of the chain metaphor in capturing the interrelationship of myriad industry players or levels of investment and recoupment. He asserted that, despite accepted usage of the term "value chain," it might be more accurately understood as a "value system." ${ }^{41}$ Consequently, enthusiasm about the potential benefits of disintermediation-in the windowless world of digital disruption-needs to be tempered by a consideration of the jurisdictional constraints present in the feature film 
value chain. Of particular relevance for national cinema are state mechanisms aimed at supporting the production and distribution of domestic intellectual property (IP).

In 2017/2018, Canadian theatrical feature film production accounted for 3 percent of the total volume of film and television production in Canada. ${ }^{42}$ Although the proportional share is consistent with the previous fiscal year, the production budget volume actually rose by 13.9 percent to CAD\$303 million. ${ }^{43}$ Taking the rest of the decade into consideration, this figure is lower than the CAD\$326 million annual average. ${ }^{44}$ The sharpest increases in the film and television production sector (as a whole) have been in the foreign location and service (FLS) segment, which has jumped by over 300 percent in a decade to just under CAD\$4.8 billion (or 53 percent of the CAD\$8.9 billion total). ${ }^{45}$ Some of the FLS expansion has been attributed to increased SVOD spending from Netflix, Amazon, and Hulu. ${ }^{46}$ The disproportionate growth of the FLS sector raises questions about how Netflix is contributing to Canadian production. For domestic IP in the theatrical feature film production sector, approximately 58 percent of the financing comes from public sources, such as tax credits and funding from Telefilm Canada. ${ }^{47}$ Eligibility for different levels of public support hinges, in part, on certification as a Canadian program. Certification criteria assess levels of production and postproduction spending in Canada, involvement of a Canadian producer "as the central decision-maker from the development stage," and points allocated for "key creative functions being performed by Canadians." ${ }^{48}$ Telefilm's Canada Feature Film Fund requires a minimum of 8 out of 10 points (with the exception of treaty coproductions). ${ }^{49}$ Public support for Canadian productions also carries stipulations about distribution in Canada. For projects budgeted at or above CAD\$2.5 million, the Feature Film Fund requires a commitment from a Canadian distributor for a domestic theatrical release. ${ }^{50}$ These regulatory protections could create barriers for a theatrical production seeking financial involvement from Netflix.

The feature production environment in Australia reflects many of the attributes that mark the Canadian context. While FLS production represents a smaller facet of the industryaccounting for approximately 35 percent of all film and television production in Australia, compared to the 25 percent share held by Australian feature films (including official coproductions ${ }^{51}$-dynamic growth in this area, particularly around foreign TV production, ${ }^{52}$ raises questions about how foreign actors like Netflix fit within existing domestic screen ecologies. Flipping the perspective of national productions seeking Netflix involvement to instead ask "what incentive do OTT services have to contribute to domestic feature film production?" further highlights the mechanisms at work in state-supported industries that shape feature film production. Although foreign investors (including distributors and producers) account for the largest single source of finance for Australian features at 36 percent of total finance in 2018/2019, it is government support in the form of tax offsets and direct funding that account for almost half of all funding (33 percent from the Producer Offset tax concession and 15 percent in direct funding). ${ }^{53}$ Such government support comes with specific requirements: for the Producer Offset, all productions must contain "significant Australian content," 54 while feature films-which receive the higher offset of 40 percent compared to 20 percent for other productions-are defined by their theatrical release, with the understanding that "applicants should plan to earn a meaningful proportion of the project's revenue from the Australian theatrical box office." ${ }^{n 5}$ While significantly supporting domestic production for access by domestic audiences, these stipulations also act as potential barriers 
to providers seeking windowless releasing. As with Canada, then, there exists within the Australian production policy framework significant questions about how domestic film production might engage transnational OTT services and what incentive such services would have to operate within the existing national feature film value chain.

\section{Netflix and Film Festivals}

In the value chain's progression from script to screen, film festivals persist as a threshold space-as sites where both completed products and new projects can accrue symbolic capital (potentially convertible as box office returns or development financing) or economic capital (through acquisition or ancillary market sales). As de Valck has noted, film festivals serve as sites of cultural legitimization-from program selection and awards competitions to the prestigious atmosphere of red carpet premieres to the "rich discursive context that encourages discussion, reflection, and engagement." ${ }^{" 56}$ For Netflix, the top-tier international film festivals have become a key battleground in struggles over the future of windowed releasing. Their ongoing dispute with the Cannes Film Festival over award eligibility for films that refuse to comply with France's minimum requirements for theatrical release ${ }^{57}$ highlights the stakes for new models of art cinema distribution. TIFF (Toronto International Film Festival) has taken a position in the debate through their programming of Netflix-produced feature films, including the selection of Outlaw King (2018) for the prestigious Opening Gala slot. In the context of the Canadian festival sector, the presence of Netflix arguably has further coalesced attention on TIFF, as a singular national top-tier event. For example, Roma (2018) screened only at TIFF prior to a limited theatrical release in three Canadian cities, often in festival-owned venues like the Vancity Theatre ${ }^{58}$ (the year-round facility of the Vancouver International Film Festival).

If Netflix has embraced the potential of top-tier festivals as avenues for raising attention and prestige, their releasing strategy also demonstrates a disinterest in the longer tail of the festival circuit, where the majority of Australian film festivals sit. Where films might once have circulated for upward of a year or eighteen months through the loosely formed networks of major, mid-sized, and specialized film festivals that form international film festival circuits, for many films this festival run is being cut far shorter. Director of the Perth Revelation Film Festival, Richard Sowada, has observed this change in the "festival window" as films move from festival runs to VOD release:

Where films screened in Cannes (May), Toronto and Venice (September) or IDFA [nternational Documentary Film Festival Amsterdam] (November) would easily find a place at Australian international film festivals the following year, these titles are now often well circulating the on demand environment a matter of two or three months after their initial fest premieres. ${ }^{59}$

While this shortening of the festival window signals a challenge for festival programmers, it also has an impact on national feature film production systems. Festivals provide launchpads not only for films, but also for their creative teams (producers, directors, writers), acting as sites for building professional networks and sourcing support for future projects. ${ }^{60}$ National industries that often cannot fund feature projects solely within a domestic market 
rely on the value addition provided by festivals for both films and filmmakers in order to support ongoing production and development. Although top-tier festivals provide key sites for this, it is often the repeat interactions provided by festival circuits that help to build film and filmmaker reputations.

As a move that seemingly counteracts this negative trend, Netflix's involvement with film festivals has extended to sponsorship of industry-related activities. As the presenting sponsor of the Canadian Film Centre's annual TIFF BBQ (a high-profile networking event and fundraiser for the Centre's talent-development initiatives), ${ }^{61}$ the streaming service can assert a more cinephilic brand image in the context of festival guests and screen industry VIPs. In addition, investments made in conjunction with the 2017 Netflix deal (a CAD\$500 million commitment approved under the Canada Investment Act ${ }^{62}$ have the potential to support industry capacity in the domestic sector. Specifically, a portion of the CAD\$25 million earmarked for market development forms the basis of a three-year deal to support TIFF's Canadian film industry programs (including the Talent Accelerator and TIFF Filmmaker Lab). ${ }^{63}$

Although these investments provide professional development opportunities for Canadian creative talent, it remains unclear whether the Netflix deal will result in increased production and distribution of domestic IP (given the aforementioned challenges presented by legacy funding models). TIFF also faces pushback from major sponsors, including Bell Media (owner of domestic OTT service Crave) and exhibitor Cineplex, who have banished Netflix titles from their Scotiabank Theatre (one of TIFF's screening venues). ${ }^{64}$ Looking at these public and highly publicized entanglements with the film festival sector, it is useful to recall Zboralska and Davis' assessment of Netflix's brand image as "an emancipatory and innovative disruptor of the much-derided Canadian status quo." ${ }^{\prime 5}$ Although they were focused on consumer-related strategies (e.g., lax enforcement of Virtual Private Network [VPN] usage to circumvent territorial rights management), a similar thread can be seen in Cameron Bailey's defense of TIFF's programming decisions-discussing the festival's inclusion of SVOD titles, TIFF's Artistic Director and Co-Head indicated that they "follow the best industry talent" and "don't discriminate in terms of seeking films from one kind of source or another."66 Thus, an engagement with the value of cinema, as it is negotiated in festival spaces, might contribute to destabilizing the legacy policy models that support the feature film value chain for national cinemas.

\section{Ancillary Revenue Streams}

Lacking a Netflix deal such as the one negotiated in Canada, the presence of Netflix within the arenas of domestic talent development and prestige-seeking has been less conspicuous in Australia. Despite its arrival in 2015, the official presence of Netflix in Australia remained limited, with no locally based staff employed until 2019. This changed with the establishment of a headquarters in Sydney in the latter half of 2019, as well as the recruitment of a head of publicity for Netflix originals in Australia/New Zealand and a director of public policy. ${ }^{67}$ This was followed with a more production-focused hire-director, local originals for Australia-in $2020{ }^{68}$ Yet, to date Netflix's presence in Australia has signaled a greater interest in monitoring policy debates and regulatory issues than in developing the kinds of production or development hubs established in Toronto, London, or Madrid. 
The limited interest in Australia as a major hub of production was signaled by Lisa HamiltonDaly, the US-based Director of Original Series (Drama) for English-language regions, at the Screen Producers' Association's Screen Forever conference in 2019. Hamilton-Daly acknowledged that investment in fully commissioned originals from Australia would be "probably one or two at the top [of production estimates]," with the potential for coproductions slightly higher. ${ }^{69}$ This sets a low bar for expected impact that Netflix will have on the production and distribution of Australian IP and underscores a growing push in Australia to apply content quotas to OTTs. ${ }^{70}$ Indeed, in a report on Australian content in SVOD catalogs, Lobato and Scarlata found that Netflix programmed the least amount of Australian content of any domestically available OTT service, offering only seventeen Australian films in 2019, less than 0.5 percent of its catalog. ${ }^{71}$ Where Netflix has engaged with Australian film, this has primarily occurred through acquisitions of films for worldwide streaming in late stages of productionsuch as with Cargo (2017) and I Am Mother (2019) ${ }^{72}$-or through more traditional licensing arrangements. So far, the only Australian film to have early Netflix involvement is David Michôd's The King (2019). ${ }^{73}$ While active involvement in film production in Australia remains limited, however, Netflix's presence within the region has nevertheless signaled a significant shift in local production systems.

In Australia, the expansion of OTT services has accompanied a contraction of heritage exploitation markets (home video sell-through and rental; pay TV; broadcast licenses) and with it a growing destabilization of the dominant feature film value chain that relies on such markets. At the exploitation end, the uptake of SVOD services by Australian audiences has accompanied a decline in Box Office (BO) share for art-house and locally made films. According to Screen Australia CEO Graeme Mason, the theatrical market has become increasingly hit-driven in recent years, with art-house titles now making only half what they would have made a few years ago. ${ }^{74}$ While overall the theatrical BO in Australia remains strong, up 3.1 per cent in 2018, the BO share of films playing fewer than two hundred screenswhich includes most Australian films-has dropped from 33 to 14 percent in the decade from $2007{ }^{75}$ This reduction in theatrical share coincides with diminishing revenues for films from DVD and television markets. ${ }^{76}$ While evidence of a direct correlation between OTT subscriptions and declining ancillary markets requires further investigation, there nevertheless exists a perception within the local industry that the transition to a market built on "digital cents for physical dollars" is underwriting the declining value of heritage ancillary markets for feature films. ${ }^{77}$

Despite diminishing returns, the consolidation and contraction of ancillary revenue streams in the Australian context have placed a growing pressure on films "to at least break even in the theatrical window," according to Studiocanal Australasia CEO Elizabeth Trotman. ${ }^{78}$ This growing pressure on theatrical returns holds implications not only for a film's profitability but also for the larger production pipeline, with growing uncertainty around the amount of revenue film projects can generate, causing significant disruption to the means of financing such productions. In a recent public lecture on the growing uncertainty of the Australian film sector, producer Sue Maslin noted that the established model of approaching distributors for guarantees and advances, of pre-selling international territories and seeking production loans based on sales estimates, has changed significantly. ${ }^{79}$ Distributors are increasingly cautious in acquiring films at script stage or in providing advances to support 
production, ${ }^{80}$ while the changing heritage markets have removed certainty from sales estimates. The result is a significant shift in the value chain for local productions, with key gaps opening up at both the front-end (financing) and back-end (exploitation) stages.

\section{Segregated Ancillary Catalogs}

In the Canadian context, the growth of OTT services has tended to focus anxiety on how the broadcasting sector supports the feature film value chain-via contributions to the Canada Media Fund (CMF; which are linked to the revenue earned by broadcast distribution undertakings [BDUs]) and the regulatory requirement to program domestic content. ${ }^{81}$ These anxieties about Canadian TV networks "as a primary pillar for the feature-film industry" 82 have roots in the rise of pick-and-pay television and an increasingly competitive consumer landscape. In 2015, Scott Henderson, communications vice-president for Bell Media (owner of specialty channel TMN, The Movie Network), explained that "as a premium movie service, TMN seeks to prelicense promotable big-budget theatrical films with marquee cast." ${ }^{13}$ Henderson's statement was made in response to complaints about reduced spending by specialty channels on Canadian acquisition rights. A few years later, in 2018, TMN was merged with CraveTV, Bell Media's OTT service. With OTT services exempt from the regulatory requirements faced by domestic BDUs, concerns escalate about eroding the foundations of Canadian content production, while calls increase for leveling the playing field (either through regulatory relief for broadcasters or by regulating the involvement of foreign-owned OTT services in the domestic market).

Changes to the 2019-2020 CMF guidelines included broadened definitions of "Canadian Broadcaster" and "Canadian Broadcast Right" that encompass online programming undertakings in a manner consistent with the Canadian Radio-television and Telecommunications Commission's (CRTC) technologically neutral (or platform agnostic) interpretation of broadcasting. The elaboration of the Canadian Broadcast Right refers to "any broadcast or online platforms the Canadian Broadcaster owns, operates and controls in Canada," ${ }^{84}$ which means that the core exploitation rights associated with license fees include OTT services like Crave. In an article in Toronto's Now magazine about whether Netflix should be legally required to produce Canadian content, Radheyan Simonpillai points out that Crave "only boasts an extensive CanCon library because those films and TV shows are already produced or licensed by its parent company's cable services. ${ }^{175}$ Simonpillai insinuates that even Crave's catalog would not survive a "doomsday scenario" ${ }^{\text {" }}$ in which cord cutting and unregulated streaming services decimate the CMF and commitments to domestic content. Despite this gloomy perspective on Canadian content regulation, production financing does not seem to fully account for the absence of culturally Canadian films (i.e., features funded based on Telefilm's criteria) in the Canadian Netflix catalog. Presumably, after the initial exclusivity period expires, long-tail distribution rights could continue to be exploited on additional SVOD services. However, an examination of Netflix's Canadian catalog suggests that their approach to acquiring theatrically released Canadian features focuses predominantly on international acclaim-with internationally recognizable talent or acknowledgment from the Academy Awards. ${ }^{87}$ What this means for how viewers might encounter national cinema on SVOD 
services is that the culturally Canadian feature films are mostly on Crave and on US Netflixdue to digital rights management restrictions-but rarely on Canadian Netflix.

The availability of Canadian films on different SVOD services raises questions about audience access and discoverability. In a 2017 Canadian Audience Report prepared by Nielsen for Telefilm Canada, 61 percent of respondents reported that they watch live action feature films on Netflix, whereas only 6 percent reported watching films on Crave. ${ }^{88}$ The disparity in engagement with different online subscription services needs to be considered alongside how digital rights management limits the Netflix catalog for Canada's geographically bounded national audience. If the majority of Canadians are watching films on Netflix, but most of the Canadian films are on Crave, then discoverability is about much more than platform algorithms. Indeed, if access to Canadian content hinges on subscription preferences, the resulting scenario is worse than ghettoizing Canadian cinema on the foreign film shelf in the video store-now, most of the films are not even in the same "store." With no regulatory incentive for Netflix Canada to participate in the legacy mechanisms for supporting the domestic feature film industry, there is a risk of starving the ancillary release windows for domestic content.

\section{Conclusion}

The effects of the rise of Netflix, alongside OTT SVOD services more broadly, are already being felt within the global media environment. However, several questions remain regarding what the long-term impact of their continued spread will be. For state-supported feature film production industries, the disruptions produced by services like Netflix become clearest when assessing their interactions with established value chain models. As shown in our examination of Canada and Australia, policy mechanisms designed to foster national cinema present barriers for the participation of foreign-owned SVOD services. Specifically, support for the development of domestic IP is tied to ensuring access to domestic theatrical audiences, thus limiting the opportunities for windowless releasing and invoking the jurisdictional constraints of territorial rights management. For services that operate OTT of the regulatory systems that govern domestic content delivery, there appears to be little incentive to find ways to engage with legacy funding models. Growth in the foreign location and service production sector suggests that there are limits to how much foreign actors like Netflix are localizing their investment in domestic screen ecologies.

The main objective of this article has been to interrogate the tendency to classify Netflix as television-in order to consider the potential expansion of cinema's ecosystem when digital portals engage with film industry logics. In doing so, we aimed to avoid "either/or" approaches that pit internet-distribution technologies against legacy exhibition models (such that portals with hybrid catalogs are viewed as ancillary platforms). By equating entertainment services like Netflix with television, the discussion of how feature films navigate the value chain tends to be reduced to a focus on (linear) release windows at the expense of an exploration of the reconfiguration of film industry logics. We found that disruptions in the festival sector-ranging from reduced festival circuit runs to stakeholder and sponsor pushback over Netflix's involvement-could contribute to destabilizing legacy value system 
frameworks. It is important to note that the role of film festivals as cultural gatekeepers includes discursive engagement with value addition and that this might, in turn, contribute to the perceived inevitability of the changes wrought by digital distribution. In looking to the future of national cinemas, indeed to cinema more broadly, critical attention needs to shift to exploring how existing value chain and exploitation models can adapt to a changing screen environment. Asking the question-what if Netflix is cinema-is a necessary step in approaching this task.

${ }^{1}$ Dr Diane Burgess teaches in the School of Journalism, Writing, and Media at the University of British Columbia. Her research explores value creation in the film festival sector, cultural policy, and the intermediary role of festivals in the context of national screen industries. She co-wrote a chapter about research methodology in Film Festivals: History, Theory, Method, Practice (Routledge) and a chapter about BC Cinema in Self: Portraits: The Cinemas of Canada Since Telefilm (The Canadian Film Institute). Her work has also appeared in Canadian Journal of Film Studies, NECSUS European Journal of Media Studies, CineAction, and Canadian Journal of Communication.

${ }^{2}$ Dr Kirsten Stevens lectures in the school of Culture and Communication at the University of Melbourne. Her research explores the impacts of digital technology, gender and the influence of film festivals and film culture events within national screen industries. She is the author of Australian Film Festivals: Audience, Place and Exhibition Culture (Palgrave Macmillan 2016) and co-editor of Screening Scarlett Johansson: Gender, Genre, Stardom (Palgrave Macmillan 2019) and Transnational German Cinema: Encountering Germany Through Film and Events (Springer 2021). Her work has also appeared in Camera Obscura, New Review of Film and Television Studies and Studies in Australasian Cinema.

${ }^{3}$ Ramon Lobato, Netflix Nations: The Geography of Digital Distribution (NY: New York University Press, 2019), 20.

${ }^{4}$ Over-the-top (OTT) services operate independently from delivery networks (like cable, satellite, or internet service providers). Canada. Canadian Radio-television and Telecommunications Commission (CRTC), Results of the Fact-Finding Exercise on the Over-the-Top Programming Services, October 2011, 1, https://crtc.gc.ca/ eng/publications/reports/rp1110.pdf.

${ }^{5}$ Amanda D. Lotz, Ramon Lobato, and Julian Thomas, "Internet-Distributed Television Research: A Provocation," Media Industries 5 (2, 2018): 35-47.

${ }^{6}$ Ibid., 40.

${ }^{7}$ Scott Roxborough, "No Netflix Films in Cannes for Second Year Running," The Hollywood Reporter, April 18, 2019, https://www.hollywoodreporter.com/news / no-netflix-films-cannes-second-year-running-1202596.

${ }^{8}$ Barry Hertz, "Why Mudbound Deserves to be Seen on the Largest Screen Possible," The Globe and Mail, November 16, 2017, https://www.theglobeandmail.com/ arts/film/why-mudbound-deserves-to-be-seen-on-the-largest-screenpossible/ article37001397/.

${ }^{9}$ Lotz et al., "Internet-Distributed Television Research," 36. 
${ }^{10}$ Ramon Lobato and Amanda D. Lotz, "Imagining Global Video: The Challenge of Netflix," Journal of Cinema and Media Studies 59 (3, 2020): 133.

${ }^{11}$ Ibid.

${ }^{12}$ Lotz et al., "Internet-Distributed Television Research," 40.

${ }^{13}$ Ramon Lobato, "The Politics of Digital Distribution: Exclusionary Structures in Online Cinema," Studies in Australasian Cinema 3 (2, 2009): 168, doi:10.1386/ sac.3.2.167/1.

${ }^{14}$ For example, Lobato, "The Politics of Digital Distribution"; Kevin McDonald and Daniel Smith-Rowsey, eds, The Netflix Effect: Technology and Entertainment in the 21st Century (NY: Bloomsbury, 2016); Chuck Tryon, On-Demand Culture: Digital Delivery and the Future of Movies (New Brunswick, NJ: Rutgers University Press, 2013).

${ }^{15}$ For example, Ian Huffer, "NZ Film On Demand: Searching for National Cinema Online," Continuum Journal of Media E Cultural Studies 30 (6, 2016): 697-705, doi:10. 1080/10304312.2016.1231794.

${ }^{16}$ For example, Jennifer Hessler, "Quality You Can't Touch: Mubi Social, Platform Politics, and the Online Distribution of Art Cinema," The Velvet Light Trap 82 (2018): 3-17, https://muse.jhu.edu/article/702286; Roderik Smits and E. W. Nikdel, "Beyond Netflix and Amazon: MUBI and the Curation of On-Demand Film," Studies in European Cinema 16 (1, 2019): 22-37, https://doi.org/10.1080/17411548.2018.1554775.

${ }^{17}$ Alexander Fisher, "African Cinema On Demand? The Politics of Online Distribution and the Case of the African Film Library," Journal of African Media Studies 10 (3, 2018): 246, doi:10.1386/jams.10.3.239_1.

${ }^{18}$ Smits traces the discussion of distribution and gatekeeping from "disintermediation" to "re-intermediation." Roderik Smits, "Film Distribution: A Changing Business," in DVD, Blu-Ray and Beyond: Navigating Formats and Platforms Within Media Consumption, ed. Jonathan Wroot and Andy Willis (Basingstoke: Palgrave Macmillan, 2017), 115-34, doi:10.1007/978-3-319-62758-8_7. Fisher ("African Cinema On Demand?") offers the term "new intermediation."

${ }^{19}$ Malte Hagener, "Cinephilia and Film Culture in the Age of Digital Networks," in The State of Post-Cinema: Tracing the Moving Image in the Age of Digital Dissemination, ed. Malte Hagener, Vinzenz Hediger, and Alena Strohmaier (London: Palgrave Macmillan, 2016), 181-94, doi:10.1057/978-1-137-52939-8_11.

${ }^{20}$ For example, Hessler, "Quality You Can't Touch."

${ }^{21}$ For example, Huffer, "NZ Film On Demand."

${ }^{22}$ Wheeler Winston Dixon, "What Happened? The Digital Shift in Cinema," Senses of Cinema, October 2019, http://sensesofcinema.com/2019/cinema-in-the-2010s / what-happened-the-digital-shift-in-cinema/.

${ }^{23}$ Mattias Frey, "The Internet Suggests: Film, Recommender Systems, and Cultural Mediation," Journal of Cinema and Media Studies 59 (1, 2019): 163-69.

${ }^{24}$ Ibid.

${ }^{25}$ Dixon, "What Happened?"

${ }^{26}$ Frey, "The Internet Suggests," 164.

${ }^{27}$ Ibid.

${ }^{28}$ Mattias Frey, "Netflix Crit in the Twenty-First Century," Film Criticism 40 (1, 2016), http://dx.doi.org/10.3998/fc.13761232.0040.111. 
${ }^{29}$ The inclusion of Canada's French-language market is beyond the scope of the comparative analysis undertaken here. French-language content production (and feature film value chain) would benefit from further elaboration to unpack how the impact of OTT services tends to be framed from an English-Canadian perspective.

${ }^{30}$ Annette Van Den Bosch and Alison Beale, "Australian and Canadian Cultural Policies: A Feminist Perspective," in Ghost in the Machine: Women and Cultural Policy in Canada and Australia, ed. Alison Beale and Annette Van Den Bosch (Toronto: Garamond, 1998), 1-21.

${ }^{31}$ Ibid.

${ }^{32}$ It was an inauspicious start, as news broke on Twitter that the company had sent paid extras to the Toronto launch event with an instruction sheet advising them "to look really excited, particularly if asked by the media to do any interviews about the prospect of Netflix in Canada." "Netflix Offers 'Phenomenal Deal'; Paid Actors at Downtown Launch Instructed to 'Look Really Excited', 'The Toronto Star, September 23, 2010, p. B1.

${ }^{33}$ Australia. Australian Communications and Media Authority, Communications Report 2017-18, February 15, 2019, 77, https://www.acma.gov.au/publications/2019-02/ report/communications-report-2017-18.

${ }^{34}$ Vito Pilieci, "Swimming Up Streams: Why Watching Online TV Is Getting So Very Complicated," Ottawa Citizen, April 11, 2019, https://ottawacitizen.com/news / local-news /swimming-up-streams-why-watching-online-tv-is-getting-so-verycomplicated.

${ }^{35}$ Emily Jackson, "Netflix Doing Booming Business in Canada, Industry Research Reports Suggest," Financial Post, April 17, 2018, https://business.financialpost. com/telecom/media/netflix-doing-booming-business-in-canada-industryresearch-reports-suggest.

${ }^{36}$ Stuart Heritage, "Why Does Netflix Keep Making So Many Cheap TV Movies?" The Guardian (International Edition), July 10, 2019, https://www.theguardian.com/ film/2019/jul/10/netflix-secret-obsession-tv-movies.

${ }^{37}$ Peter Bloore, "Re-defining the Independent Film Value Chain," UK Film Council, February 2009, https://www.bfi.org.uk/sites/bfi.org.uk/files/downloads/rede fining-the-independent-film-value-chain.pdf.

${ }^{38}$ Keith Kehoe and John Mateer, "The Impact of Digital Technology on the Distribution Value Chain Model of Independent Feature Films in the UK," International Journal on Media Management 17 (2, 2015): 93-108, doi:10.1080/14241277.2015.1055533.

${ }^{39}$ Stuart Cunningham and Jon Silver, Screen Distribution and the New King Kongs of the Online World (Basingstoke: Palgrave Macmillan, 2013), 4, doi:10.1057/ 9781137326454.

${ }^{40}$ Canada. Canadian Radio-television and Telecommunications Commission (CRTC), New Media, Public Notice CRTC 1999-84, May 17, 1999, point 33, https://crtc.gc.ca/ eng/archive/1999/pb99-84.htm.

${ }^{41}$ Bloore, "Re-defining," 2-4.

${ }^{42}$ Canadian Media Producers Association (CMPA), in collaboration with the Department of Canadian Heritage, Telefilm Canada, the Association québécoise de la production médiatique (AQPM), and Nordicity, Profile 2018 Economic Report on 
the Screen-Based Media Production Industry in Canada, 2018, 9, https://cmpa.ca/ wp-content/uploads/2019/06/CMPA_2018_ENG_J20_ONLINE.pdf.

${ }^{43}$ Ibid., 8.

${ }^{44}$ Ibid., 45.

${ }^{45}$ Ibid., 8.

${ }^{46}$ Loren Malyk, "Production Spend in B.C. Up 31\% in 2017/18," Playback (July 18, 2017), quoted in CMPA, Profile 2018, 60.

${ }^{47}$ CMPA et al., Profile 2018, 45.

${ }^{48}$ Canada. Canadian Radio-television and Telecommunications Commission (CRTC), Canadian Program Certification Guide, last modified January 7, 2020, https://crtc. gc.ca/canrec/eng/guide1.htm\#5.2.

${ }^{49}$ Telefilm Canada, Canada Feature Film Fund-Guidelines, February 7, 2019, 2, https:// telefilm.ca/en/financing/production.

${ }^{50}$ Ibid., 3.

${ }^{51}$ Screen Australia, Drama Report: Production of Feature Films, TV and Online Drama in Australia in 2018/19, October, 2019, 5, https://www.screenaustralia.gov.au/sa/mediacentre/news /2019/10-31-drama-report-2018-19-australian-titles\#: :text=Of\%20 the $\% 20$ Australian\%20productions $\% 20$ tracked,production\%20funding\%20from\%20 Screen\%20Australia.

${ }^{52}$ Foreign TV production rose by almost 290 percent in 2018/2019 compared to the previous year-AUD\$4 million in 2017/2018 to AUD\$115 million-and was 261 percent above the five-year average. Ibid., 23.

${ }^{53}$ Ibid., 9.

${ }^{54}$ Significant Australian Content is legislated as including subject matter, production location, the nationalities of people involved in the film, qualifying Australian production expenditure, and "any other matters that the film authority considers to be relevant." Australia. Income Tax Assessment Act 1997 (Cth) s 376-70(1) https:// www.legislation.gov.au/Details/C2015C00237/Html/Volume_7\#_Toc418511622.

${ }^{55}$ Screen Australia, Producer Offset Guidelines, December 1, 2018, 13, https://www. screenaustralia.gov.au /getmedia /dca7da14-7350-4203-a332-c5115cfff996 / Guidelines-producer-offset.pdf.

${ }^{56}$ Marijke de Valck, "Fostering Art, Adding Value, Cultivating Taste: Film Festivals as Sites of Cultural Legitimization," in Film Festivals: History, Theory, Method, Practice, ed. Marijke de Valck, Brendan Kredell, and Skadi Loist (London: Routledge, 2016), 106.

${ }^{57}$ Roxborough, "No Netflix Films in Cannes."

${ }^{58}$ Tom Charity notes that Netflix "wanted assurances that we could project the film on $4 \mathrm{~K}$ and with a 5.1 Dolby sound system ... insisting on optimal standards of presentation for what is, after all, a deluxe experience." Tom Charity, "A Room for Roma," VIFF Blog, December 12, 2018, https://blog.viff.org/2018/12/12/a-roomfor-roma/.

${ }^{59}$ Richard Sowada, "The New Film Festival Half-Life," While I Think of It (blog), December 7, 2016, https://richardsowada.wordpress.com/2016/12/07/the-newfilm-festival-half-life/.

${ }^{60}$ Marijke de Valck, Film Festivals: From European Geopolitics to Global Cinephilia (Amsterdam: Amsterdam UP, 2007), 38. 
${ }^{61}$ See http://cfccreates.com/about/events/35.

${ }^{62}$ Canada. Canadian Heritage, Launch of Netflix Canada: A Recognition of Canada's Creative Talent and Its Strong Track Record in Creating Films and Television [News Release], September 28, 2017, https://www.canada.ca/en/canadian-heritage/ news/2017/09/launch_of_netflixcanadaarecognitionofcanadascreativetalentan dits.html.

${ }^{63}$ Etan Vlessing, "Netflix, Toronto Film Fest Partner to Develop Local Movie Talent," The Hollywood Reporter, November 5, 2019, https://www.hollywoodreporter.com / news/netflix-toronto-film-fest-partner-develop-local-movie-talent-1252412.

${ }^{64}$ Ibid.

${ }^{65}$ Emilia Zboralska and Charles Davis, "Transnational Over-the-Top Media Distribution as a Business and Policy Disruptor: The Case of Netflix in Canada," The Journal of Media Innovations 4 (1, 2017): 12, http://dx.doi.org/10.5617/jmi.v4i1.2423.

${ }^{66}$ Vlessing, "Netflix, Toronto Film Fest."

${ }^{67}$ Ramon Lobato and Stuart Cunningham, "Netflix Is Opening its First Australian HQ. What Does This Mean for the Local Screen Industry?" The Conversation, June 19, 2019, https://theconversation.com/netflix-is-opening-its-first-australian-hqwhat-does-this-mean-for-the-local-screen-industry-118903.

${ }^{68}$ Dan Groves, "Netflix Hires the ABC's Que Minh Luu," If.Com.Au, June 19, 2020, https://www.if.com.au/netflix-hires-the-abcs-que-minh-luu/.

${ }^{69}$ David Tiley, "Entering the Netflix Maze From Australia," ScreenHub, 20 November, 2019, https://www.screenhub.com.au/news-article/opinions-and-analysis/digital/ david-tiley/entering-the-netflix-maze-from-australia-259274.

70 The Make It Australian Campaign was initiated in 2018, calling on the government to protect the country's screen industry by extending Australian content rules to "new media like Netflix, Amazon, Telstra TV, telcos and ISPs." Make It Australian, "Open Letter to Federal Parliamentarians," Make It Australian, March 26, 2018, https:// makeitaustralian.com/news/open-letter.

${ }^{71}$ Ramon Lobato and Alexa Scarlata, Australian Content in SVOD Catalogs: Availability and Discoverability - 2019 Edition (Melbourne: RMIT University, 2019), 10.

${ }^{72}$ Each of these films also had a short festival and theatrical run in Australia, allowing them to meet eligibility requirements for Government subsidies and AACTA (Australian Academy of Cinema and Television Arts) Awards.

73 The King won four awards at the 2019 AACTA Awards, including for cinematography, supporting actor, production design, and costume design. AACTA waived the usual eligibility requirements for The King to compete-Award films must usually have had a theatrical release or qualifying festival screening in Australia, while The King had neither. The Netflix production was deemed Australian despite its Shakespearian/English historical story and European setting due to Australians occupying the key creative roles of Director, Writer, and Producer. Jackie Keast, "Thirty-Four Features to Compete for AACTA Awards, Including Netflix's The King," If.Com.Au, September 10, 2019, https://www.if.com.au/thirty-four-features-tocompete-for-aacta-awards-including-netflixs-the-king/.

${ }^{74}$ Graeme Mason, "Voice of the Industry," IF Magazine 181 (February-March 2018): 6.

${ }^{75}$ Ibid. 
${ }^{76}$ Dan Groves, "Graeme Mason Tells Producers: Get Smarter about the Rapidly Changing World," IF Magazine, March 12, 2018, https://www.if.com.au/graeme mason-tells-producers-get-smarter-about-the-rapidly-changing-theatricalmarket/.

77 Jackie Keast, "Shrinking Window," IF Magazine 183 (June-July 2018): 19.

${ }^{78}$ Ibid.

${ }^{79}$ Sue Maslin, "Embracing Uncertainty: Preparing for a Future at the Intersection of Creativity, Business and Screen Technologies," Public Lecture, School of Media and Communication, RMIT University, Melbourne, Australia, August 27, 2019.

${ }^{80}$ Keast, "Shrinking Window," 19.

${ }^{81}$ Australia is unlike Canada in this respect: broadcasters face content requirements that encourage investment but do not contribute directly to a media fund.

${ }^{82}$ Simon Houpt, "What Is Wrong with the Canadian Film Industry?" The Globe and Mail, September 4, 2015, https://www.theglobeandmail.com/arts/awards-andfestivals /tiff/the-shaky-future-of-canadiancinema/article26225432/.

${ }^{83}$ Ibid.

${ }^{84}$ Canada Media Fund (CMF), Summary of Changes 2019-2020, March 2019, 5, https:// cmf-fmc.ca/getattachment/0d7b36d8-e66c-47ff-ab2a-e64c4d939154/attachment.aspx.

${ }^{85}$ Radheyan Simonpillai, "Should Canada Legally Force Netflix to Produce CanCon?" NOW Magazine, July 9, 2019, https://nowtoronto.com/movies/features/netflixcrave-canada-streaming-legislation/.

${ }^{86}$ Ibid.

${ }^{87}$ Diane Burgess, "TIFF: Netflix and Streaming Means Canadian Features Struggle to Find Audiences," The Conversation, September 2, 2019, https://theconversation. com/tiff-netflix-and-streaming-means-canadian-feature-films-struggle-to-findaudiences-121851.

${ }^{88}$ Telefilm Canada, Canadian Audience Report [prepared by Nielsen Media Research], November 2017, 34, https://telefilm.ca/en/studies/canadian-audience-report.

\section{Bibliography}

Australia. Australian Communications and Media Authority (ACMA). Communications Report 2017-18, February 15, 2019. https://www.acma.gov.au/publications/2019-02/report/ communications-report-2017-18.

Australia. Income Tax Assessment Act 1997 (Cth) s 376-70(1). https://www.legislation.gov.au/ Details/C2015C00237/Html/Volume_7\#_Toc418511622.

Bloore, Peter. "Re-defining the Independent Film Value Chain." UK Film Council, February 2009. https://www.bfi.org.uk/sites/bfi.org.uk/files/downloads/redefining-theindependent-film-value-chain.pdf.

Burgess, Diane. "TIFF: Netflix and Streaming Means Canadian Features Struggle to Find Audiences." The Conversation, September 2, 2019. https://theconversation.com/ 
tiff-netflix-and-streaming-means-canadian-feature-films-struggle-to-find-audi ences-121851.

Canada. Canada Media Fund (CMF). Summary of Changes 2019-2020, March 2019, https:// cmf-fmc.ca/getattachment/0d7b36d8-e66c-47ff-ab2a-e64c4d939154/attachment. aspx.

Canada. Canadian Heritage. Launch of Netflix Canada: A Recognition of Canada's Creative Talent and Its Strong Track Record in Creating Films and Television [News Release]. September 28, 2017. https://www.canada.ca/en/canadian-heritage/news/2017/09/launch_ of_netflixcanadaarecognitionofcanadascreativetalentandits.html.

Canada. Canadian Media Producers Association(CMPA), in collaboration with the Department of Canadian Heritage, Telefilm Canada, the Association québécoise de la production médiatique (AQPM) and Nordicity. Profile 2018 Economic Report on the ScreenBased Media Production Industry in Canada, 2018. https://cmpa.ca/wp-content/ uploads/2019/06/CMPA_2018_ENG_J20_ONLINE.pdf.

Canada. Canadian Radio-television and Telecommunications Commission (CRTC). Canadian Program Certification Guide. Last modified January 7, 2020. https://crtc.gc.ca/canrec/eng/guide1.htm\#5.2.

Canada. Canadian Radio-television and Telecommunications Commission(CRTC), New Media, Public Notice CRTC 1999-84, May 17, 1999. https://crtc.gc.ca/eng/archive/1999/ pb99-84.htm.

Canada. Canadian Radio-television and Telecommunications Commission (CRTC). Results of the Fact-Finding Exercise on the Over-the-Top Programming Services, October 2011. https://crtc.gc.ca/eng/publications/reports/rp1110.pdf.

Charity, Tom. "A Room for Roma." VIFF Blog, December 12, 2018. https://blog.viff.

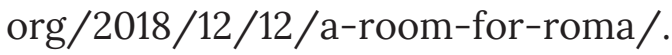

Cunningham, Stuart, and Jon Silver. Screen Distribution and the New King Kongs of the Online World. Basingstoke: Palgrave Macmillan, 2013. doi:10.1057/9781137326454.

de Valck, Marijke. Film Festivals: From European Geopolitics to Global Cinephilia. Amsterdam: Amsterdam UP, 2007.

de Valck, Marijke. "Fostering Art, Adding Value, Cultivating Taste: Film Festivals as Sites of Cultural Legitimization." In Film Festivals: History, Theory, Method, Practice, edited by Marijke de Valck, Brendan Kredell, and Skadi Loist, 100-116. London: Routledge, 2016.

Dixon, Wheeler Winston. "What Happened? The Digital Shift in Cinema." Senses of Cinema, October 2019. http://sensesofcinema.com/2019/cinema-in-the-2010s/whathappened-the-digital-shift-in-cinema/.

Fisher, Alexander. "African Cinema On Demand? The Politics of Online Distribution and the Case of the African Film Library." Journal of African Media Studies 10, no. 3 (2018): 239-50. doi:10.1386/jams.10.3.239_1.

Frey, Mattias. "The Internet Suggests: Film, Recommender Systems, and Cultural Mediation." Journal of Cinema and Media Studies 59, no. 1(2019): 163-69. 
Frey, Mattias. "Netflix Crit in the Twenty-First Century." Film Criticism 40, no. 1 (2016). http://dx.doi.org/10.3998/fc.13761232.0040.111.

Groves, Dan. "Graeme Mason Tells Producers: Get Smarter about the Rapidly Changing World." IF Magazine, March 12, 2018. https://www.if.com.au/graeme-mason-tellsproducers-get-smarter-about-the-rapidly-changing-theatrical-market/.

Groves, Dan. "Netflix Hires the ABC's Que Minh Luu," If.Com.Au, June 19, 2020. https://www. if.com.au/netflix-hires-the-abcs-que-minh-luu/.

Hagener, Malte. "Cinephilia and Film Culture in the Age of Digital Networks." In The State of Post-Cinema: Tracing the Moving Image in the Age of Digital Dissemination, edited by Malte Hagener, Vinzenz Hediger, and Alena Strohmaier, 181-94. London: Palgrave Macmillan, 2016. doi:10.1057/978-1-137-52939-8_11.

Heritage, Stuart. "Why Does Netflix Keep Making So Many Cheap TV Movies?" The Guardian (International Edition), July 10, 2019. https://www.theguardian.com/film/2019/ jul/10/netflix-secret-obsession-tv-movies.

Hertz, Barry. "Why Mudbound Deserves to be Seen on the Largest Screen Possible." The Globe and Mail, November 16, 2017. https://www.theglobeandmail.com/arts/film/whymudbound-deserves-to-be-seen-on-the-largest-screenpossible/article37001397/.

Hessler, Jennifer. "Quality You Can't Touch: Mubi Social, Platform Politics, and the Online Distribution of Art Cinema." The Velvet Light Trap, no. 82 (2018): 3-17. https://muse. jhu.edu/article/702286.

Houpt, Simon. "What Is Wrong with the Canadian Film Industry?" The Globe and Mail, September 4, 2015. https://www.theglobeandmail.com/arts/awards-and-festivals / tiff/the-shaky-future-of-canadiancinema/article26225432/.

Huffer, Ian. "NZ Film On Demand: Searching for National Cinema Online." Continuum: Journal of Media E Cultural Studies 30, no. 6 (2016): 697-705. doi:10.1080/10304312.2016 .1231794 .

Jackson, Emily. "Netflix Doing Booming Business in Canada, Industry Research Reports Suggest." Financial Post, April 17, 2018. https://business.financialpost.com/telecom/ media/netflix-doing-booming-business-in-canada-industry-research-reportssuggest.

Keast, Jackie. "Shrinking Window." IF Magazine 183 (June-July 2018): 18-19.

Keast, Jackie. "Thirty-Four Features to Compete for AACTA Awards, Including Netflix's The King." If.Com.Au, September 10, 2019. https://www.if.com.au/thirty-four-featuresto-compete-for-aacta-awards-including-netflixs-the-king/.

Kehoe, Keith, and John Mateer. "The Impact of Digital Technology on the Distribution Value Chain Model of Independent Feature Films in the UK." International Journal on Media Management 17, no. 2 (2015): 93-108. doi:10.1080/14241277.2015.1055533.

Lobato, Ramon. Netflix Nations: The Geography of Digital Distribution. New York: New York University Press, 2019. 
Lobato, Ramon. "The Politics of Digital Distribution: Exclusionary Structures in Online Cinema." Studies in Australasian Cinema 3, no. 2 (2009): 167-78. doi:10.1386/ sac.3.2.167/1.

Lobato, Ramon, and Alexa Scarlata, Australian Content in SVOD Catalogs: Availability and Discoverability-2019 Edition. Melbourne: RMIT University, 2019. https://apo.org. $\mathrm{au} /$ node/264821.

Lobato, Ramon, and Amanda D. Lotz. "Imagining Global Video: The Challenge of Netflix." Journal of Cinema and Media Studies 59, no. 3 (2020): 132-36.

Lobato, Ramon, and Stuart Cunningham. "Netflix Is Opening its First Australian HQ. What Does This Mean for the Local Screen Industry?" The Conversation, June 19, 2019. https://theconversation.com/netflix-is-opening-its-first-australian-hq-whatdoes-this-mean-for-the-local-screen-industry-118903.

Lotz, Amanda D., Ramon Lobato, and Julian Thomas. "Internet-Distributed Television Research: A Provocation." Media Industries 5, no. 2 (2018): 35-47. http://dx.doi. org/10.3998/mij.15031809.0005.203.

Make It Australian. "Open Letter to Federal Parliamentarians." Make It Australian March 26, 2018. https://makeitaustralian.com/news/open-letter.

McDonald, Kevin, and Daniel Smith-Rowsey, eds. The Netflix Effect: Technology and Entertainment in the 21st Century. New York: Bloomsbury, 2016.

Malyk, Loren. "Production Spend in B.C. Up 31\% in 2017/18." Playback, July 18, 2017. http:// playbackonline.ca/2018/07/18/production-spend-in-b-c-climbs-to-3-4bin-201718/.

Maslin, Sue. "Embracing Uncertainty: Preparing for a Future at the Intersection of Creativity, Business and Screen Technologies." Public Lecture, School of Media and Communication, RMIT University, Melbourne, Australia, August 27, 2019.

Mason, Graeme. "Voice of the Industry." IF Magazine 181 (February-March 2018): 6.

"Netflix Offers 'Phenomenal Deal'; Paid Actors at Downtown Launch Instructed to 'Look Really Excited."' The Toronto Star, September 23, 2010, p. B1.

Pilieci, Vito. "SwimmingUp Streams: Why Watching Online TV Is Getting So Very Complicated." Ottawa Citizen, April 11, 2019. https://ottawacitizen.com/news/local-news/ swimming-up-streams-why-watching-online-tv-is-getting-so-very-complicated.

Roxborough, Scott. "No Netflix Films in Cannes for Second Year Running." The Hollywood Reporter, April 18, 2019. https://www.hollywoodreporter.com/news/no-netflixfilms-cannes-second-year-running-1202596.

Screen Australia. Producer Offset Guidelines, December 1, 2018. https://www.screenaustralia.gov.au/getmedia/dca7da14-7350-4203-a332-c5115cfff996/Guidelines-produceroffset.pdf.

Screen Australia. Drama Report: Production of Feature Films, TV and Online Drama in Australia in 2018/19. October,2019.https://www.screenaustralia.gov.au/getmedia/08d8518b867b-4f61-8c2e-ebd10f0dc3a4/Drama-report-2018-2019.pdf?ext=.pdf. 
Simonpillai, Radheyan. "Should Canada Legally Force Netflix to Produce CanCon?" NOW Magazine, July 9 2019. https://nowtoronto.com/movies/features/netflix-cravecanada-streaming-legislation/.

Smits, Roderik. "Film Distribution: A Changing Business," in DVD, Blu-Ray and Beyond: Navigating Formats and Platforms Within Media Consumption, edited by Jonathan Wroot and Andy Willis, 115-34. Basingstoke: Palgrave Macmillan, 2017. doi:10.1007/9783-319-62758-8_7.

Smits, Roderik, and E. W. Nikdel. "Beyond Netflix and Amazon: MUBI and the Curation of On-Demand Film." Studies in European Cinema 16, no. 1(2019): 22-37. https://doi.org/ 10.1080/17411548.2018.1554775.

Sowada, Richard. "The New Film Festival Half-Life." While I Think of It (blog), December 7, 2016. https://richardsowada.wordpress.com/2016/12/07/the-new-film-festivalhalf-life/.

Telefilm Canada. Canada Feature Film Fund-Guidelines, February 7, 2019. https://telefilm. ca/en/financing/production.

Telefilm Canada. Canadian Audience Report [prepared by Nielsen Media Research], November 2017. https://telefilm.ca/en/studies/canadian-audience-report.

Tiley, David. "Entering the Netflix Maze From Australia." ScreenHub November 20, 2019. https://www.screenhub.com.au/news-article/opinions-and-analysis/digital/ david-tiley/entering-the-netflix-maze-from-australia-259274.

Tryon, Chuck. On Demand Culture: Digital Delivery and the Future of Movies. New Brunswick, NJ: Rutgers University Press, 2013.

Van Den Bosch, Annette, and Alison Beale. "Australian and Canadian Cultural Policies: A Feminist Perspective," in Ghost in the Machine: Women and Cultural Policy in Canada and Australia, edited by Alison Beale and Annette Van Den Bosch, 1-21. Toronto: Garamond, 1998.

Vlessing, Etan. "Netflix, Toronto Film Fest Partner to Develop Local Movie Talent." The Hollywood Reporter, November 5, 2019. https://www.hollywoodreporter.com/ news/netflix-toronto-film-fest-partner-develop-local-movie-talent-1252412.

Zboralska, Emilia, and Charles Davis. "Transnational Over-the-Top Media Distribution as a Business and Policy Disruptor: The Case of Netflix in Canada." The Journal of Media Innovations 4, no. 1 (2017): 4-25. http://dx.doi.org/10.5617/jmi.v4i1.2423. 
